\title{
Relationship between accounting benefits and ERP user satisfaction in the context of the fourth industrial revolution
}

\author{
${ }^{1}$ Thanh Hung Nguyen, ${ }^{2}$ Minh Thanh Do, ${ }^{3}$ Quang Trong Vu \\ Accounting and Auditing Faculty, ThuongMai University, Vietnam
}

\begin{abstract}
the context of 4th Industrial Revolution, the application of information technology to optimize business processes is more popular. Resource planning system (ERP) is applied by enterprises as an efficient solution to save costs and manage resources effectively. Besides, the application of ERP creates accounting benefits for end users. We conduct this study to determine the accounting benefits of ERP application. At the same time, we explore the relationship between these accounting benefit and user satisfaction. To achieve the aims of this research, the study employed empirical techniques like the Exploratory Factor Analysis (EFA) and Multiple Linear Regression. Research results show that a number of accounting benefits derived from the application of ERP that focus on the following four dimensions: operational, information technology, organizational, and management. The study provided evidence of the relationship between accounting benefits in terms of ERP application and user satisfaction as accountants. The study contributed to encourage Vietnamese enterprises to apply ERP to increase the value of accounting benefits. From there, these benefits contribute to providing timely and flexible information for management levels.
\end{abstract}

Keywords: 4th Industrial Revolution, ERP, accounting benefits, user satisfaction.

\section{Introduction}

The world is entering the fourth industrial revolution with the trend of the internet connecting everything, artificial intelligence, intelligent robots, blockchain technology, cloud computing... (European Parliament, 2016). This revolution has a strong and comprehensive impact on the global economy, society, and environment. It also affects all sectors and fields with unprecedented technological speed in history, including accounting and auditing (Đặng, 2018). In this context, by recognizing the risks as well as the potentials, businesses have invested in technology to improve production capacity, innovate products and services creatively, reduce costs and create more added value for customers. ERP is becoming a modern management tool and is becoming more and more popular.

Enterprise resource planning systems integrate several business procedures, applications and departments while sharing one database and assist companies in responding to real-time information (Nicolaou 2003, Rom and Rohde 2006, Spathis 2006, Stefanou 2002). ERP systems have significantly changed the way business data is collected, stored, disseminated and used. This change in information processing orientation affects the accounting process (Sutton, 2006). If the ERP system is successfully implemented, it will bring many benefits to businesses in many ways, including benefits on the overall level of the enterprise and benefits at the department level, including the accounting department. Research by Booth, Matolcsy, and Wieder (2000), Fahy and Lynch (1999), Granlund and Malmi (2000), Maccarrone (2000), have shown that the successful implementation of ERP provides common benefits such as transactions are processed more efficiently, information access and the synthesis of the report are formed faster, and the quality of information is improved. The accountants are surveyed in the research of Spathis \& Ananiadis (2005) suggest that the application of ERP brings many benefits to the accounting information system. Besides, the research of Gargeya and Brady (2005), Oliver (1999), confirms that the accounting benefits in the ERP environment are the accounting values and efficiency after successful ERP implementation. These benefits include assistance in quickly collecting, processing, extracting accounting data and ensuring the 
confidentiality of information. Moreover, the application of ERP increases the flexibility and reliability of accounting information, and contributes to improving internal control functions throughout the enterprise.

In recent years, the construction enterprises in Vietnam have made strong development, making an important contribution to the economic growth and development of Vietnam. In the context of integration and the explosion of technology 4.0, construction enterprises must constantly invest in advanced and modern construction technologies to improve the construction capacity and quality of construction works in order to improve the competitiveness of construction products. Construction enterprises are characterized by a wide area of operation, scattered human resources and resources, with affiliated units and many departments involved in the operation process of enterprises. Therefore, the accounting department plays an important role in mobilizing and allocating resources, providing useful information for administrators, helping them perform effective management functions. Currently, Vietnamese construction enterprises have been effectively implementing information technology application with ERP system to manage and operate enterprises. ERP system has become an effective control tool in the enterprise, making an important contribution to reducing costs and lowering construction product costs, in order to create a competitive advantage, towards sustainable development (Nguyễn, 2015). Although many studies have focused on the benefits of ERP application, there have been no studies on the accounting benefits and ERP user satisfaction level, especially in construction businesses in Vietnam.

The main purpose of our study is to investigate the accounting benefits that the application of ERP by Construction companies in Vietnam can create about as well as the relationship between accounting benefits and ERP user satisfaction level. The paper is structured with 5 parts: in addition to the introduction, the second part present an overview of the research and research questions, the third part discuss the research methodology, the fourth part present the research results and the final section provides conclusions and recommendations.

\section{Literature review and research questions}

\subsection{Accounting benefits in terms of ERP application}

In the relevant literature, there were research studies focusing on the interaction between ERP systems and accounting. Spathis and Constantinides (2004) examined the reasons behind enterprises' decision to replace the traditionally information systems (IS) with completed ERP systems and explored the changes that occur in terms of accountant applications. The study of Booth, Matolcsy, and Wieder (2000) examined the extent to which ERP application can lead to changes in the accounting process of an enterprise. The paper provided evidence to show that the ERP system contributes more effectively to the handling of arising economic operations than the traditional accounting information system. When adopt of ERP system, accessing information is carried out easier by the accounting department, the business process is improved by integrating data from all functional departments. These benefits help the accounting department to analyze, process and provide financial information and non-financial information more timely for administrators to help them make decisions more quickly and appropriately.

In addition to the studies on the impact of ERP on the accounting process, some authors mentioned the impact of the ERP system on the role of accountants in businesses. Granlund and Malmi (2002), Rom and Rohde (2006) pointed out the effects of integrated information systems such as ERP systems on management accounting as well as the role of management accountant. Research results have shown that the quick processing of input data is a good deal of important accounting benefit in the context of ERP application. These have led to management accountants to have more time to focus on analyzing and supporting executive decisions. These findings were in line with the findings of Scapens and Jazayeri's (2003), who claimed that the works of management accountants has been positively altered when businesses adopted the ERP system. The management accountant's role has focused more interpretative instead of focusing activities and transactions as before. Grabski, Leech, and Schmidt (2011) stated that approaching and applying ERP system significantly changed the role of accountants. As a result, accountants need to be equipped with the necessary skills to meet the job in the new condition.

Shang and Seddon (2002) have shown that, when applying ERP, businesses can gain benefits on five aspects, include as follow: operational benefits, management benefits, strategic benefits, organizational benefits, and information technology of infrastructure benefits. Inheriting the research of Shang and Seddon 
(2002), Spathis (2006) surveyed enterprises applying ERP in Greece and show that ERP systems bring benefits, organizational benefits, operational benefits in terms of time, management benefits, operating benefits in terms of costs, information technology benefits. Increased flexibility in creating relevant information, improving the quality of accounting reports, the enhancement of decision-making ability based on timely and reliable accounting information are the accounting benefits indicated in the study. This result is consistent with the research of Spathis and Ananiadis (2005). Research by Kanellou and Spathis (2013) reinforced the accounting benefits that ERP brings to businesses. In addition, Järvenpää (2007) has demonstrated that the quick and flexible processing and exploitation of data on large digital databases is one of the outstanding benefits of ERP. This benefit contributes to creating quality management reports that better for demand of administrators.

In summary, recent studies have shown that the application of ERP brings accounting benefits and affects the accounting process, the accounting department and the accountant's role. Therefore, we conduct a comprehensive study of accounting benefits under the conditions of applying ERP. At the same time, it specifies the groups of factors derived from these benefits. For this purpose, the first research question is as follows:

\section{What are the accounting benefits derived from the adoption of ERP systems in Vietnamese enterprises and which are the main factors into which these benefits could be categorized?}

\subsection{Satisfaction of users of ERP system}

In the relevant literature, there are many researches which try to evaluate the success and overall performance of an information system in general or an ERP system in particular through the measurement of perceived user satisfaction. Somers, Nelson, and Karimi (2003) described user satisfaction as the extent to which a user perceives that a system meets his or her information requirements. They note that user satisfaction with information systems is one of the most important determinants of the success of those systems.

From another perspective of user satisfaction, Calisir and Calisir (2004) conducted a survey of factors affecting the satisfaction of end-user ERP systems. The results show that the awareness of the usefulness and benefits of ERP are the key factors to the satisfaction of users of ERP systems. Users can assess their satisfaction by comparing the benefits gained after implementing an ERP with the expectation before deploying this system. The more effective businesses deploy and apply ERP, the more benefits they will have. However, these benefits are perceived and assessed differently by different users, the satisfaction of each group of system users may vary (Zviran, Pliskin \& Levin, 2005).

Longinidis and Gotzamani (2009) surveyed accountants - users of ERP systems and pointed out that their satisfaction derives from the accounting benefits of ERP implementation and application. With the same research results, Saatcioglu (2009) believed that more benefits of deploying ERP, the higher the satisfaction of users. On the contrary, the higher the users' appreciate the benefits of an ERP, the higher their satisfaction.

Other empirical studies conducted by Caglio (2003), Newman and Westrup (2005) demonstrated that there is a relationship between accounting benefits and the application of ERP, and a clear perception of accounting benefits from accountants. Perceptions of accountant satisfaction - end users increase through benefits such as, information flexibility is increased, applications are integrated, and data processing speed is improved. In addition, Saatcioglu (2009) also pointed out that the successful implementation of EPR system will bring many benefits to businesses. In contrast, the enterprise information system will be at risk if the implementation of the ERP project fails. Barriers such as high costs, qualification requirements of the operator, and system complexity could be the reasons for the failure of an ERP implementation. However, he found that, if ERP is implemented successfully, the five most important benefits which determine user satisfaction are "better management and controlling functions," "financial flow controls," "information flow controls," "increased IT infrastructure capability" and "control of flow of goods."

Based on the results of the above overview, the implementation and application of ERP system could bring accounting benefits to businesses. These benefits are one of the factors affect the accountants' perception of ERP systems. Meanwhile, users' satisfaction is assessed based on this perception. On the other hand, Kanellou and Spathis (2013) have successfully conducted research to explore the relationship between ERP 
user satisfaction and accounting benefits at businesses that have applied ERP in Greece. Therefore, in this study, we examine the relationship at businesses in Vietnam. To achieve this research objective, the second research question is given as follows:

\section{Is there a relation between ERP user satisfaction and accounting benefits at Vietnamese enterprises? How is the influence of each accounting benefits on user satisfaction?}

\section{Methodology}

The current study tries to evaluate perceived ERP benefits concerning accounting process and whether these accounting benefits affect ERP user satisfaction. A quantitative approach was adopted in terms of the collection and analysis of the data. The data were gathered by means of the self-completed, written questionnaire method. ERP accounting benefits questions were based on benefits lists' developed or used by previous research studies (Deloitte Consulting 1998, Esteves 2009, O'Leary 2004, Spathis 2006). From the list of benefits, the research only uses benefits directly related to accounting activities.

Before conducting the official survey, we conducted a pilot survey of 26 accountants at 6 construction enterprises that have applied ERP. The application period for these enterprises is over 1 year and was in Hanoi city. Feedback from pilot-study testing was used to refine the format of the questionnaire items by addition, removal, or rephrasing of items as necessary. A five-point Likert scale $(1=$ not at all, $5=$ excellent degree) was created for this study.

The empirical evidence is obtained via the questionnaire. Additional confirmatory evidence on the validity of the scale used is presented in the following sections on the factor analysis result. Further, regarding the reliability of those factors, Cronbach's alpha is estimated. As the next step, Pearson's correlation was used to examine the linear relationship between the independent variables (accounting benefits dimension) and the dependent variables (user satisfaction) and between the independent variables. Finally, the multiple linear regression model was performed to test the relationship between accounting benefits and ERP user satisfaction, as well as the degree of influence of each accounting benefits on the satisfaction.

This study selected accountants, general accountants, and chief accountants in Vietnamese construction enterprises to participate in the survey. These participants are considered having full knowledge, use, and appreciation of accounting benefits under the conditions of applying ERP rather than those of other parts of the enterprise such as IT, business, marketing ... Respondents participating in the survey are sent in two forms: direct and email. We sent total of 386 questionnaires to the survey subjects. After 4 months, the research team received 258 responses, accounting for $66.83 \%$. Due to personal relationships, the survey response rate has been quite high. After processing and screening the collected questionnaires, 225 used surveys were processed into the SPSS 22.0 software for analysis.

\section{Results}

Among 225 survey questionnaires used for researching purposes, $76 \%$ of the respondents were accountants, 38 of them were general accountants, 16 of them were chief accountants, accounting respectively for $16.9 \%$ and $7.1 \%$ of the total (Table 1). Regarding work experience, employees with the number of years of work from 3 to 5 years in enterprises accounted for the highest proportion (48.4\%), followed by the number of years of experience from 5-9 years at the rate of 36\%. Among ERP suppliers for construction enterprises in Vietnam, foreign suppliers accounted for $53.1 \%$ (17/32 surveyed enterprises), the rest was provided by domestic enterprises. This result shows that foreign-origin ERP software is still preferred among surveyed enterprises.

\begin{tabular}{|l|c|c|}
\hline & Frequency & $\%$ \\
\hline Position in the firm & & \\
\hline Accountant & 171 & 76 \\
\hline General Accountant & 38 & 16.9 \\
\hline Chief accountant & 16 & 7.1 \\
\hline Total & 225 & 100 \\
\hline Experience (years) & & \\
\hline$<3$ & 20 & 8.9 \\
\hline
\end{tabular}




\begin{tabular}{|c|c|c|}
\hline 03-May & 109 & 48.4 \\
\hline 05-Sep & 81 & 36 \\
\hline$>9$ & 15 & 6.7 \\
\hline Total & 225 & 100 \\
\hline \multicolumn{3}{|l|}{ Type of ERP } \\
\hline Foreign ERP provider (SAP, Oracle, ERP Construction...) & 16 & 50 \\
\hline Vietnam ERP provider (Bravo 7, SINNOVA-ERP, Fast Business, ...) & 13 & 50 \\
\hline Total & 32 & 100 \\
\hline \multicolumn{3}{|l|}{ Time since ERP adoption (years) } \\
\hline$<2$ & 29 & 12.9 \\
\hline 02-May & 141 & 62.7 \\
\hline$>5$ & 55 & 24.4 \\
\hline Total & 225 & 100 \\
\hline
\end{tabular}

\subsection{Accounting benefits in terms of ERP application}

Respondents have quoted a number of benefits and advantages in accounting processes and practice derived from ERP systems. Details are displayed in Table 2 which show that mean of accounting benefits are greater than 3.0, in which, the benefit of "Improved follow-up of assets" is assessed at the highest level (4.30). In contrast, "reduce data extraction time" is the accounting benefit with the lowest rating (3.42). The results in Table 2 also show that the respondents appreciated other accounting benefits such as, improved working capital control, increased use of financial ratio analysis, reasonably operational budget, improving decisionmaking process. This result was explained that integrate business applications in the ERP system provides the real-time data shared across the organization and consequently the integration and automation of business processes. This result helps users to control cash flow better, financial ratios are provided more fully, more relevant information is provided not only for cost estimation but also for effective decision support. In contrast, reduction of time for transaction processing, increase the productivity of the accounting department, less time for annual closing of accounts, reduction of time for extracting data are accounting benefits that are among the lowest-rated group. These finding are consistent with previous studies by Spathis and Constantinides (2004) at 26 companies in Greece and the UK, Spathis (2006) at 73 enterprises, Esteves (2009) at 78 small and medium enterprises applying ERP in Spain, as well as research results of Kanellou and Spathis (2013) at 193 enterprises in Greece.

\section{Table 2: Accounting benefits in terms of ERP application}

\begin{tabular}{|l|c|c|c|c|}
\hline Accounting benefits & Min & Max & Mean & SD \\
\hline 1. Improved follow-up of assets & 3 & 5 & 4.3 & 0.586 \\
\hline 2. Improved working capital control & 2 & 5 & 4.25 & 0.641 \\
\hline 3. Increased use of financial ratio analysis & 2 & 5 & 4.23 & 0.66 \\
\hline 4. Make more reasonable operational budget & 2 & 5 & 4.22 & 0.649 \\
\hline 5. Improved decision-making process & 2 & 5 & 4.19 & 0.738 \\
\hline 6. Less time for preparing and issuing reports & 2 & 5 & 3.75 & 0.682 \\
\hline 7. Fewer errors on data entry & 2 & 5 & 3.64 & 0.871 \\
\hline 8. Increased flexibility on information provision & 2 & 5 & 3.65 & 0.874 \\
\hline 9. Improved quality of reports & 1 & 5 & 3.59 & 1.006 \\
\hline 10. Improved internal audit function & 2 & 5 & 3.59 & 0.913 \\
\hline $\begin{array}{l}\text { 11. The accounting department communicates easier with other } \\
\text { departments } \\
\text { within the organization }\end{array}$ & 1 & 5 & 3.57 & 1.046 \\
\hline 12. ERP gathers data more quickly & 1 & 5 & 3.57 & 0.993 \\
\hline 13. Improve the efficiency of database use & 1 & 5 & 3.55 & 0.944 \\
\hline 14. Decreased total operational cost & 1 & 5 & 3.54 & 0.906 \\
\hline 15. ERP gathers data easier & 2 & 5 & 3.53 & 0.935 \\
\hline
\end{tabular}




\begin{tabular}{|l|l|l|l|l|}
\hline 16. Increased integration of applications & 1 & 5 & 3.52 & 1.023 \\
\hline 17. Less time for document entry & 2 & 5 & 3.52 & 0.955 \\
\hline 18. Reduction of time for transaction processing & 1 & 5 & 3.52 & 0.936 \\
\hline 19. Increase the productivity of the accounting department & 1 & 5 & 3.52 & 0.907 \\
\hline 20. Less time for annual closing of accounts & 2 & 5 & 3.46 & 0.945 \\
\hline 21. Reduction of time for extracting data & 1 & 5 & 3.42 & 0.903 \\
\hline
\end{tabular}

As can be seen in Table 3, principal component analysis and varimax with Kaiser normalization rotation methods pointed to a total of four factors ( 21 observations), which explain 62.30 percent of the total variance. This percentage is particularly high and is considered satisfactory. The evaluation of the number of factors was carried out using the eigenvalue criterion, which was greater than the unitary. The analysis revealed a clear structure between the factors and the loading of the corresponding variables. The KaiserMeyer-Olkin measure of sampling adequacy is high (0.888), suggesting that factor analysis is appropriate for this data set. Bartlett's test of sphericity is large (2165.083) and the associated significance level is small $(0.000<0.05)$, therefore it is unlikely that the population matrix is an identity. Furthermore, the factors have high alpha values (between 0.884 and 0.719 ) confirming their high reliability (Hair, Black, Babin, Anderson, \& Tatham, 2006).

Table 3: Factor analysis and reliability scores of ERP system benefits

\begin{tabular}{|c|c|c|c|}
\hline & Factor Loadings & $\%$ of variance & Cronbach's Alpha \\
\hline Factor 1: Operational accounting benefits $(O P A B)$ & & 18.481 & 0.874 \\
\hline - Less time for preparing and issuing reports & 0.873 & & \\
\hline - Fewer errors on data entry & 0.757 & & \\
\hline - Less time for document entry & 0.746 & & \\
\hline - Increase the productivity of the accounting department & 0.725 & & \\
\hline - Less time for annual closing of accounts & 0.722 & & \\
\hline - Decreased total operational cost & 0.722 & & \\
\hline Factor 2: IT accounting benefits (ITAB) & & 16.195 & 0.884 \\
\hline - ERP gathers data easier & 0.816 & & \\
\hline - ERP gathers data more quickly & 0.798 & & \\
\hline - Reduction of time for extracting data & 0.798 & & \\
\hline - Reduction of time for transaction processing & 0.774 & & \\
\hline - Improve the efficiency of database use & 0.72 & & \\
\hline Factor 3: Organizational accounting benefits (ORAB) & & 16.138 & 0.871 \\
\hline - Improved quality of reports & 0.831 & & \\
\hline - Increased flexibility on information provision & 0.812 & & \\
\hline - Improved co-ordination between accounting and others department & 0.801 & & \\
\hline - Improved internal audit function & 0.783 & & \\
\hline - Increased integration of applications & 0.702 & & \\
\hline Factor 4: Managerial accounting benefits (MAAB) & & 11.485 & 0.719 \\
\hline - Improved decision-making process of managers & 0.736 & & \\
\hline - Increased use of financial ratio analysis & 0.733 & & \\
\hline - Improved follow-up of assets & 0.655 & & \\
\hline - Make more reasonable operational budget & 0.649 & & \\
\hline - Improved working capital control & 0.626 & & \\
\hline Total variance explained $(\%)$ & & 62.3 & \\
\hline KMO & \multicolumn{3}{|c|}{0.888} \\
\hline P-value & \multicolumn{3}{|c|}{0} \\
\hline Df & \multicolumn{3}{|c|}{210} \\
\hline
\end{tabular}


Based on the results of Exploring Factor Analysis, the study found four accounting benefit dimensions derived from the application of ERP in Vietnamese construction enterprises. Accounting benefit dimensions are based on the benefit classification in the term of ERP application by Kanellou and Spathis (2013), Shang and Seddon (2002) and Spathis (2006). At the same time, they are based on the "descriptive method" that reflects the names of the elements in each dimension according to Kim and Mueller (1978). This list of accounting benefits is consolidated into five benefits dimensions as the following:

Operational accounting benefits: Less time for preparing and issuing reports, fewer errors on data entry, less time for document entry, increase the productivity of the accounting department, less time for annual closing of accounts, decreased total operational cost.

Information technology (IT) accounting benefits: ERP gathers data easier, ERP gathers data more quickly, reduction of time for extracting data, reduction of time for transaction processing, improve the efficiency of database use.

Organizational accounting benefits: Improved quality of reports, increased flexibility on information provision, improved co-ordination between accounting and others department, improved internal audit function, increased integration of applications.

Managerial accounting benefits: Improved decision-making process of managers, increased use of financial ratio analysis, improved follow-up of assets, make more reasonably operational budget, improved working capital control.

\subsection{Accounting benefits and user satisfaction of ERP}

To answer the second research question on the relationship between accounting benefits and ERP user satisfaction, the study uses a multiple linear regression model, in which factors according to classification of "accounting benefits" in Table 4 are independent variables, "user satisfaction of ERP" (ESAT) is a dependent variable. Pearson's coefficient used to show the magnitude and degree of the relationship between variables. The results in Table 4 show that the tested variables are correlated each other. The correlation coefficients are from weak levels (as low as 0.138) to strong levels (as high as 0.752) at the statistical significance level of 0.01 .

\section{Table 4: The correlation matrix}

\begin{tabular}{|l|c|c|c|c|c|c|c|}
\hline & Mean & Standard deviation & OPAB & ITAB & ORAB & MAAB & ESAT \\
\hline OPAB & 3.5704 & 0.6905 & 1 & $0.480^{* *}$ & $0.362^{* *}$ & $0.189^{* *}$ & $0.752^{* *}$ \\
\hline ITAB & 3.5191 & 0.7787 & - & 1 & $0.397^{* *}$ & $0.191^{* *}$ & $0.693^{* *}$ \\
\hline ORAB & 3.5822 & 0.7917 & - & - & 1 & $.138^{* *}$ & $0.447^{* *}$ \\
\hline MAAB & 4.2356 & 0.4505 & - & - & & 1 & $0.219^{* *}$ \\
\hline ESAT & 3.6015 & 0.7947 & - & - & - & - & 1 \\
\hline
\end{tabular}

Notes: * Significant at the 0.05 level (two-tailed); ** Significant at the 0.01 level (two-tailed). OPAB: Operational accounting benefits; ITAB: IT accounting benefits; ORAB: Organizational accounting benefits; MAAB: Management accounting benefits; ESAT: ERP's user satisfaction

The multivariate regression model is used to test the influence of accounting benefit factors on user satisfaction. The model is formulated as follows: ESAT $=a+b_{1}$ OPAB $+b_{2}$ ITAB $+b_{3}$ ORAB $+b_{4}$ MAAB. The regression results show the model's relevance to the research data with adjusted $\mathrm{R}^{2}$ coefficient $=0.717$ with significance level of 0.05 . This result state that four independent variables explained $71.7 \%$ of the variation of the dependent variable; the remaining $28.3 \%$ are due to non-model variables and random errors. The Durbin - Watson coefficient has a value of 2.114 , is in the range of 1.5 to 2.5 , so no autocorrelation occurs.

\section{Table 5: Relevance of the model}

Model Summary ${ }^{b}$ 


\begin{tabular}{|c|c|c|c|c|c|}
\hline Model & $\mathbf{R}$ & R square & Adjusted R Square & Std. Error of the Estimate & Durbin-Watson \\
\hline 1 & $0.850^{\mathrm{a}}$ & 0.772 & 0.717 & 0.42256 & 2.114 \\
\hline \multicolumn{6}{|c|}{ a. Predictors: (Constant), OPAB, ITAB, ORAB, MAAB } \\
\hline \multicolumn{6}{|c|}{ b. Dependent Variable: ESAT } \\
\hline
\end{tabular}

The regression results show the model's relevance to the research data with adjusted $\mathrm{R} 2$ coefficient $=0.717$ with significance level of 0.05 . This result state that four independent variables explained $71.7 \%$ of the variation of the dependent variable; the remaining $28.3 \%$ are due to non-model variables and random errors. The value of the Durbin - Watson coefficient is 2.114 and is in the range of 1.5 to 2.5 indicating that no autocorrelation occurred. The results of regression analysis on four factors affecting ERP user satisfaction are shown in Table 6 below.

\section{Table 6: Regression analysis results}

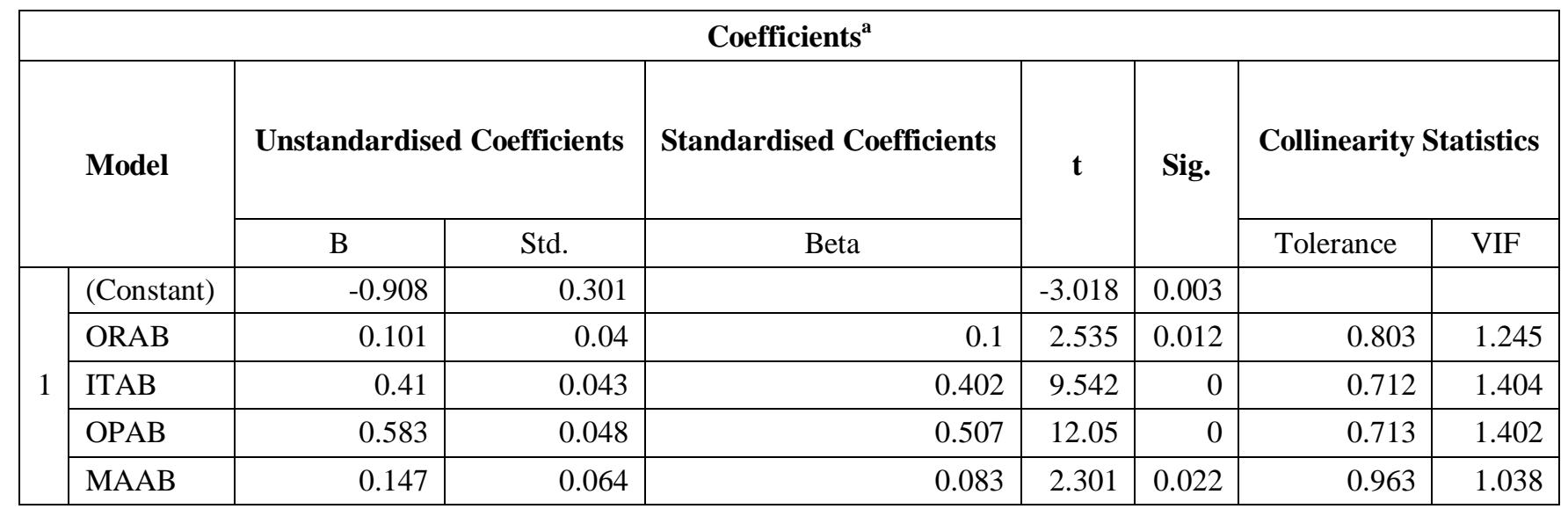

Notes: a. Dependent variable: ESAT; OPAB: Operational accounting benefits; ITAB: IT accounting benefits; ORAB: Organizational accounting benefits; MAAB: Management accounting benefits; ESAT: ERP's user satisfaction

The analysis results in Table 6 show that the estimated Beta coefficients are statistically significant at 5\% because the sig. value is less than 0.05 . Accordingly, it can be concluded that the independent variables are meant to explain the dependent variable; no variables are excluded from the model. The multicollinearity test, based on the results in the above table, is considered not occurring because the value of the variance inflation factor of the four independent variables are greater than 1. The linear regression equation showing the relationship between ERP user satisfaction and four independent variables is set as follows:

$$
\mathrm{ESAT}=-0.908+0.583 \mathrm{OPAB}+0.410 \mathrm{ITAB}+0.147 \mathrm{MAAB}+0.101 \mathrm{ORAB}
$$

The different values of the Beta in the table above show that the influence of the independent variables on the dependent variable is different.

Operational accounting benefits: From Table coefficients can be seen the results of statistical tests, where the results can be seen in the value of the beta standardized coefficients of OPAB of 0.583 with a significant value of 0.000 , which means that has a significant operational accounting benefits has positive effect on ERP user satisfaction. This can be explained that when construction enterprises apply ERP, the accounting department reduces time for document entry, decrease errors on data entry, thereby shortening the time to prepare and provide accounting reports for administrators. When other factors do not change, if operational accounting benefits increases by 1 unit, the user satisfaction increases to 0.583 units.

IT accounting benefits has the second highest impact on user satisfaction with the standardized Beta 0.410. Concerns about easy and fast data collection, convenient data extraction, reduction of time for transaction processing and improvement in data efficiency may be the reasons for this result. Positive values of standardized Beta coefficients indicate that, like operational accounting benefits, IT accounting benefits also 
positively affect the dependent variables. In other words, if IT accounting benefits increases by 1 unit, the user satisfaction increases to 0.410 units in the condition of other factors is constant.

Management accounting benefits has the third highest impact on user satisfaction with the standardized Beta 0.147. As long as other factors affecting the satisfaction of ERP users remain constant, according to these results, if management accounting benefits of ERP user management in construction enterprises is increased by 1 unit, the user satisfaction will increase to 0.147 units.

Organizational accounting benefits is the lowest impact factor on ERP user satisfaction with the standardized Beta of 0.101 . This result means that when perceiving the organizational benefits of accounting increases by 1 unit, the ERP user satisfaction will increase by 0.101 units.

\section{Conclusions and recommendations}

The aim of the present study was to investigate the accounting benefits derived from ERP application in the accounting department of construction enterprises in Vietnam, categorize these benefits into specific factors. Moreover, this study tried to evaluate the effect of accounting benefits on ERP user satisfaction. The study has shown 21 accounting benefits according to accountants' perceptions. At the same time, these benefits are categorized into four dimensions, including, operational accounting benefits, IT accounting benefits, organizational accounting benefits, management accounting benefits. The study used multiple linear regression methods to evaluate the impact of accounting benefits on the satisfaction of ERP users. The results show that 4 accounting benefits positively affect user satisfaction.

Thus, the use of ERP has brought accounting benefits to construction enterprises in Vietnam. Moreover, based on the results of this study, businesses can understand that these accounting benefits impact on the satisfaction of ERP users. Therefore, the results of the study help managers in construction enterprises have an overview and better understand the benefits that ERP brings to the accounting field. Thence, businesses have appropriate decisions to improve the quality of the ERP system, to improve the efficiency of the accounting department, to provide timely and flexible accounting information for decision-making.

The use of questionnaires, however, for primary data collection has certain limitations. Prejudices or bias that can occur when respondents respond to questionnaires can cause the data collected to be unbiased. This is considered a limitation of research. On the other hand, the study only collected perceptions of accounting benefits from the accounting department without managers - users of system information may make the ERP user satisfaction assessment of accounting benefits less than adequate. Therefore, the addition of the evaluation of managers at all levels in the enterprise should be added in the next research on this topic. At the same time, a comparison of the perceived accounting benefits of an ERP system can also be made to consider these benefits more objectively and comprehensively. Although the article has some limitations, it provides a reliable empirical result for businesses in other fields of interest, research and implementation of ERP systems in the future. In the context of the strong development of the fourth industrial revolution, the implementation of ERP system not only benefits the accounting department but also the whole enterprise.

\section{References}

[1] Booth, P., Matolcsy, Z., \& Wieder, B. (2000) the impacts of enterprise resource planning systems on accounting practice: The Australian experience. Australian Accounting Review, 10(22): 4-18. https://doi.org/10.1111/j.1835-2561.2000.tb00066.x

[2] Caglio, A. (2003) Enterprise resource planning systems and accountants: towards hybridization?. European Accounting Review, 12(1): 123- 153. https://doi.org/10.1080/0963818031000087853

[3] Calisir, F., \& Calisir, F. (2004) the relation of interface usability characteristics perceived usefulness, and perceived ease of use to end- user satisfaction with enterprise resource planning (ERP) systems. Computers in Human Behavior, 20 (4): 505-515. https://doi.org/10.1016/j.chb.2003.10.004

[4] Deloitte Consulting (1998) ERP's second wave: maximizing the value of ERP-enabled processes. New York: Author.

[5] Đặng, V.T (2018) Đổi mới quy trình kế toán trong thời đại công nghệ số, Retrived from https://tinnhanhchungkhoan.vn/thuong-truong/doi-moi-quy-trinh-ke-toan-trong-thoi-dai-cong-ngheso-242141.html. 
[6] Esteves, J. (2009) A benefits realization road-map framework for ERP usage in small and mediumsized enterprises. Journal of Enterprise Information Management, 22 (1/2): 25-35.

https://doi.org/10.1108/17410390910922804

[7] European Parliament (2016) Industry 4.0, Policy Department a: economic and scientific policy. Retrieved from

http://www.europarl.europa.eu/RegData/etudes/STUD/2016/570007/IPOL_STU(2016)570007_EN.p df.

[8] Fahy, M.J., \& Lynch, R. (1999) Enterprise Resource Planning (ERP) Systems and Strategic Management Accounting. In: The 22nd annual conference of the European Accounting Association, Bordeaux, France, 5-7 May 1999.

[9] Gargeya, V.B., \& Brady, C. (2005) Success and failure factors of adopting SAP in ERP implementation. Business Process Management Journal, 11(5): 501-516. https://doi.org/10.1108/14637150510619858

[10] Grabski, S.V., Leech, S.A., \& Schmidt, P.J. (2011) A review of ERP research: a future agenda for accounting information systems. Journal of Information Systems, (25)1: 37-78. https://doi.org/10.2308/jis.2011.25.1.37

[11] Granlund, M., \& Malmi, T. (2002) Moderate impact of ERPs on management accounting: a lag or permanent outcome? Management Accounting Research, 13(3): 299-321. https://doi.org/10.1006/mare.2002.0189

[12] Hair, J.F., Black, W.C., Babin, B.J., Anderson, R.E., \& Tatham, R.L. (2006) Mutilvariate Data Analysis .6th ed. Upper Saddle River, NJ: Prentice Hall.

[13] Järvenpää, M. (2007) Making Business Partners: a case study on how management accounting culture was changed. European Accounting Review, 16(1): 99-142. https://doi.org/10.1080/09638180701265903

[14] Kanellou, A., \& Spathis, C. (2013) Accounting benefits and satisfaction in an ERP environment, International Journal of Accounting Information Systems, 14: 209-234. https://doi.org/10.1016/j.accinf.2012.12.002

[15] Kim, J., \& Mueller, C.W. (1978). Factor Analysis: Statistical Methods and Practical Issues. SAGE Publications, Inc.

[16] Longinidis, P., \& Gotzamani, K. (2009) ERP user satisfaction issues: insights from a Greek industrial giant. Industrial Management \& Data Systems, 109(5): 628-645.

https://doi.org/10.1108/02635570910957623

[17] Maccarrone, P. (2000) The Impact of ERPs on Management Accounting and Control Systems and the Changing Role of Controllers. In: The 23rd annual conference of the European Accounting Association, Munich, Germany, , 29-31 March 2000.

[18] Newman, M., \& Westrup, C. (2005) Making ERPs work: accountants and the introduction of ERP systems. European Journal of Information Systems, 14(3): 259-272.

https://doi.org/10.1057/palgrave.ejis.3000539

[19] Nguyễn, H.P. (2015) Tổ chức kế toán trách nhiệm trong các tổng công ty xây dựng thuộc Bộ Giao thông Vận tải. PhD's Thesis, University of Economics Ho Chi Minh City, Vietnam.

[20] Nicolaou, A. (2003) Manufacturing strategy implementation and cost management systems effectiveness. European Accounting Review, 12(1): 175-199.

https://doi.org/10.1080/0963818031000087871

[21] Oliver, R.W. (1999) ERP is dead!! Long live ERP. Management Review, 88(10): 12-13.

[22] O'Leary, D.E. (2004) Enterprise resource planning (ERP) systems: an empirical analysis of benefits. Journal of emerging Technologies in Accounting, 1: 63-72. https://doi.org/10.2308/jeta.2004.1.1.63

[23] Poston, R., \& Grabski, S. (2001) financial impacts of enterprise resource planning implementations. International Journal of Accounting Information Systems, 2: 271-294. https://doi.org/10.1016/S14670895(01)00024-0

[24] Rom, A., \& Rohde, C. (2006) Enterprise resource planning systems, strategic enterprise management systems and management accounting. A Danish study. Journal of Enterprise Information Management, 19(1): 50-66. https://doi.org/10.1108/17410390610636878 
[25] Saatcioglu, O.Y. (2009) What determines user satisfaction in ERP projects: benefits, barriers or risks?. Journal of Enterprise Information Management, 22(6): 690-708. https://doi.org/10.1108/17410390910999585

[26] Scapens, R.W., \& Jazayeri, M. (2003) ERP systems and management accounting change: opportunities or impacts? A research note. European Accounting Review, 12(1): 201-233. https://doi.org/10.1080/0963818031000087907

[27] Shang, S., \& Seddon, P.B. (2002) Assessing and managing the benefits of enterprise systems: the business manager's perspective. Information Systems Journal, 12(2): 271-299. https://doi.org/10.1046/j.1365-2575.2002.00132.x

[28] Spathis, C. (2006) Enterprise systems implementation and accounting benefits. Journal of Enterprise Information Management, 19(1): 67-82. https://doi.org/10.1108/17410390610636887

[29] Spathis, C., \& Ananiadis, J. (2005) Assessing the benefits of using an enterprise system in accounting information and management. Journal of Enterprise Information Management, 18(2): 195-210. https://doi.org/10.1108/17410390510579918

[30] Spathis, C., \& Constantinides, S. (2004) Enterprise resource planning systems' impact on accounting processes. Business Process Management Journal, 10(2): 234-247. https://doi.org/10.1108/14637150410530280

[31] Somers, T.M., Nelson, K., \& Karimi, J. (2003) Confirmatory factor analysis of the end-user computing satisfaction instrument: replication with in an ERP domain. Decision Sciences, 34(3): 595-621. https://doi.org/10.1111/j.1540-5414.2003.02428.x

[32] Stefanou, J.C. (2002,) Accounting Information Systems (AIS) development/ acquisition approaches by Greek SME. In: The European Conference on Accounting Information Systems Conference (ECAIS), Copenhagen, Denmark, 23-24 April 2004. https://pdfs.semanticscholar.org/a6f6/0386ea611a328fdf2abf01a068d41b7808bd.pdf

[33] Sutton, S.G. (2006) Enterprise systems and the re-shaping of accounting systems: a call of research. International Journal of Accounting Information Systems, 7(1): 1-6. https://doi.org/10.1016/j.accinf.2006.02.002

[34] Tabachnick, B.G., Fidell, L.S., \& Osterlind, S.J. (2007) Using multivariate statistics. 5th ed. Boston: MA, Allyn \& Bacon/Pearson Education.

[35] Zviran, M., Pliskin, N., \& Levin, R. (2005). Measuring user satisfaction and perceived usefulness in the ERP context, Journal of Computer Information Systems, 45(3): 43-52.

https://doi.org/10.1080/08874417.2005.11645842 